\title{
Dermatological Aspects of COVID-19 in Nepal
}

\section{Paudel V}

Department of Dermatology and Venereology,

National Medical College,

Birgunj-19, Bhediyahi, Parsa, State 2, Nepal.

\section{Corresponding Author}

Vikash Paudel

Department of Dermatology and Venereology,

National Medical College,

Birgunj-19, Bhediyahi, Parsa, State 2, Nepal.

E-mail: vikashpoudel@iom.edu.np

\section{Citation}

Paudel V. Dermatological Aspects of COVID-19 and Nepal. Kathmandu Univ Med J. 2020;COVID-19 Special Issue 70(2):115-6.

\section{Dear Editor,}

The world has changed dramatically since the COVID-19 pandemic began. COVID-19 was first reported on 31 December 2019 at Wuhan city of China and was declared pandemic on 11 March 2020. ${ }^{1}$ In Nepal, the first case of COVID 19 was reported on 23 January 2020, on a 31 year student returnee from Wuhan. ${ }^{2}$ With change in global scenario, social, occupational, and personal lives are full of novel challenges for all physicians, including dermatologists. ${ }^{3}$

Though, there is higher the tropism of the virus for respiratory and the immune system, an epidermal barrier interruption could enhance the virus acquisition as skin has also been reported as the site of entry of virus. ${ }^{4}$ The patients might be at an increased risk for developing those viral infection. Different cutaneous manifestations are categorized into inflammatory/exanthematous and vasculopathic/vasculitic lesions. They are classified as urticarial rash, confluent erythematous/maculopapular/morbilliform rash, papulovesicular exanthem, chilblain-like acral pattern, livedo reticularis/racemosa-like pattern and purpuric "vasculitic" pattern. The most common clinical feature is maculopapular or morbilliform eruptions. ${ }^{5,6}$ The scientific understanding of COVID-19 and its dermatological symptoms is currently evolving, their pathogenic mechanisms are still unclear. However, hyperactive immune response, complement activation and microvascular injury have been implicated. ${ }^{7}$

Till today, total number of COVID-19 patient are about 12772 in Nepal, but we don't have actual prevalence of dermatological conditions among COVID-19 patients. ${ }^{8}$ However, general population, health care workers, security personnel are suffering from various dermatological condition arising indirectly due to COVID 19 crises. Dermatology's outlook in the COVID-19 pandemic is multidimensional. The dermatologists must be aware of and cautious about these skin lesions and the possibility of COVID-19 infection for prompt diagnosis and appropriate management.

In Nepal, there are about two hundred dermatologists working in different private and public hospitals and clinic across the country who are directly contact with a number of susceptible COVID patients. ${ }^{9}$ Even at some hospitals dermatologists were also forced to see the fever clinics because of lack of sufficient manpower. Many dermatological societies including society of dermatologist, venereologists and leprologist of Nepal (SODVELON) have been updating the guidelines about use of personal protective equipment (PPEs), use of immunosuppressive drugs, use of tele-dermatology services. They have advised to outweigh the risk-benefit ratio in tapering or stopping the immune-suppressive. Besides, majority of the societies advocate in using personal protective equipment, sanitizers, face-shields and mask according to the level of risk. ${ }^{10-12}$

The dermatologic manifestations like miliaria, erythema, papules, maceration, and scaling are the most commonly reported skin changes caused by extended wear of PPEs. Manifestations like burning, itching, and stinging are common with in their uses. The most commonly affected skin sites were the nasal bridge, cheeks, forehead, and hands. The prolonged contact with masks and goggles may cause contact and pressure urticaria or contact dermatitis. One-third of health care workers complained of acne, facial itching, and even dermatitis from wearing an N95 mask. The atopic diathesis, low humidity, increased frequency of hand washing, wet works, glove use, lack of moisturizers can lead to hand dermatitis. 
The prolonged use of hats may induce pruritus and folliculitis or exacerbate seborrheic dermatitis. Amidst the new normal scenario of COVID-19 pandemic, sanitizers and mask would be most commonly used even in days to come. ${ }^{13}$

A great number of public and private dermatology practices have temporarily closed. In addition, the scientific communication between dermatologists has also been disturbed with the cancellation of scientific sessions and academic meetings with rise of online webinars and symposium. The dermatologists are facing huge economic difficulties. ${ }^{14}$ The hospital and clinics should be reopened with criteria of screening all patients, physical distancing, proper sanitization, limiting non-emergency procedures and establishment of proper ventilating system.

As world is adapting with COVID crises, all health professionals including dermatologist should practice cautiously focusing on personal hygiene measures and use of precautionary measures like emollients is essential in preventing skin complications.

\section{REFERENCES}

1. World Health Organization. 2019-nCoV outbreak is an emergency of international concern. 2020. Available from: http://www. euro.who.int/en/health-topics/emergencies/pages/news/ news/2020/01/2019-ncov-outbreak-is-an-emergency-ofinternational-concern Accessed 18 June 2020.

2. Bastola A, Sah R, Rodriguez-Morales AJ et al. The first 2019 novel coronavirus case in Nepal. Lancet Infect Dis. 2020; 20(3): 279-80. https://doi.org/10.1016/S1473-3099(20)30067-0

3. Adams JG, Walls RM. Supporting the Health Care Workforce During the COVID-19 GlobalEpidemic. JAMA. 2020;323(15):1439-40. https:// doi.org/10.1001/jama.2020.3972

4. Yao XH, Li TY, He ZC, Ping YF, Liu HW, Yu SC, et al. A pathological report of three COVID-19 cases by minimally invasive autopsies. Zhonghua bing li xue za zhi= Chinese journal of pathology. 2020 Mar 15;49:E009.

5. Fahmy DH, El-Amawy HS, El-Samongy MA, Foud AA, Soliman SH, ElKady A, et al. COVID-19 and Dermatology: A Comprehensive Guide for Dermatologists. Journal of the European Academy of Dermatology and Venereology. 2020 May 19.

6. Galván Casas, C., Català, A., Carretero Hernández, G., RodríguezJiménez, P., Fernández-Nieto, D., Rodríguez-Villa Lario, et al. Classification of the cutaneous manifestations of COVID -19: a rapid prospective nationwide consensus study in Spain with 375 cases. [published online ahead of print, $2020 \mathrm{Apr} 29$ ]. Br J Dermatol. 2020;10.1111/bjd.19163. https://doi.org/10.1111/bjd.19163

7. Marzano AV, Cassano N, Genovese G, Moltrasio C, Vena GA. Cutaneous manifestations in patients with COVID-19: A preliminary review of an emerging issue. $\mathrm{Br} J$ Dermatol. 2020;10.1111/bjd.19264. https://doi.org/10.1111/bjd.19264

8. COVID-19 Corona virus pandemic. As on $28^{\text {th }}$ June 2020 . Available from https://www.worldometers.info/coronavirus/

9. Shrestha S. Access to dermatological care in Nepal (World Skin Summit). [Internet] published in International League of Dermatological Societies. [Cited 2020 June 28] Available from: https://drive.google.com/file/d/10_RaR4DMaXgVrLZ5wgQk2-ZTtg1Y_SL/view?usp=sharing

10. Consensus/Policy of SODVELON on current COVID-19 crisis. [Internet] published 15 April 2020. Nepal: Society Of Dermatologists Venereologist and Leprologists, 2020 [cited 2020 June 28] Available from: https://docs.google.com/viewerng/ viewer?url=http:// sodvelon.com/wpcontent/uploads/2020/04/covid-19-SODVELONstatement-for-Dermatological-and-cosmetic practice-final.pdf

11. American Academy of Dermatology. Guidance on the use of immunosuppressive agents. [Internet]. United States of America: American Academy of Dermatology; 2020 [cited 2020 June 28]. Available from: https://www.aad.org/member/practice/coronavirus/ clinical-guidance/biologics

12. British Association of Dermatologist. Dermatology advice regarding self-isolation and immunosuppressed patients: Adults, Paediatrics and Young People [Internet]. London: British Association of Dermatologists; 2020 [cited 2020 June 28]. Available from: https:// www.bad.org.uk/healthcare-professionals/covid-19/covid-19-\%20 immunosuppressed-patient

13. Darlenski R, Tsankov N. COVID-19 pandemic and the skin: what should dermatologists know? Clin Dermatol. 2020 (In Press) https:// doi.org/10.1016/j.clindermatol.2020.03.012

14. Wollina, U. Challenges of COVID-19 pandemic for dermatology. Dermatologic Therapy. 2020;e13430. https://doi.org/10.1111/ dth.13430 